IRA-International Journal of Applied Sciences ISSN 2455-4499; Vol.04, Issue 02 (2016)

Institute of Research Advances

Pg. no. 275-283

http://research-advances.org/index.php/IRAJAS

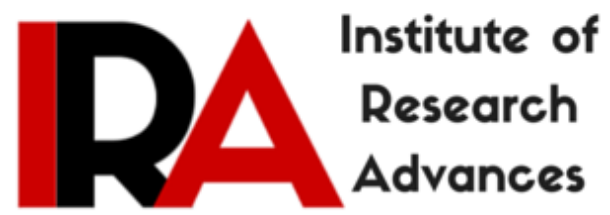

\title{
Weed management practices on winter French bean (Phaseolus vulgaris L.) under western Uttar Pradesh conditions
}

\author{
Narinder Panotra ${ }^{1}$ \& Ashwani Kumar ${ }^{2}$ \\ ${ }^{1}$ Scientist; RARS-Rajouri, Sher-e-Kashmir University of Agricultural Sciences \\ \&Technology of Jammu, Chatha, Jammu \& Kashmir, India. \\ ${ }^{2}$ VLO, Dept. of Agriculture, Zone Vijaypur, SAMBA (J\&K), India.
}

Type of Review: Peer Reviewed.

DOI: http://dx.doi.org/10.21013/jas.v4.n2.p8

\section{How to cite this paper:}

Panotra, N., \& Kumar, A. (2016). Weed management practices on winter French bean (Phaseolus vulgaris L.) under western Uttar Pradesh conditions. IRA-International Journal of Applied Sciences, 4(2), 275-283. doi:http://dx.doi.org/10.21013/jas.v4.n2.p8

(C) Institute of Research Advances

(cc) EY-NC

This work is licensed under a Creative Commons Attribution-Non Commercial 4.0 International License subject to proper citation to the publication source of the work.

Disclaimer: The scholarly papers as reviewed and published by the Institute of Research Advances (IRA) are the views and opinions of their respective authors and are not the views or opinions of the IRA. The IRA disclaims of any harm or loss caused due to the published content to any party. 


\section{ABSTRACT}

A Field investigation was conducted during the Rabi season of 2003-04 and 2004-05 at Baraut, Uttar Pradesh, to find out most suitable weed management practices on winter French bean. Among the 12 weed management treatments in French bean viz. weedy check, hand weeding at 30 days after sowing, weed free, fluchloralin @ $0.75 \mathrm{~kg} / \mathrm{ha}$, fluchloralin@1.0 kg/ha, fluchloralin @ 0.75 $\mathrm{kg} / \mathrm{ha}$ with hand weeding at 30 days after sowing, pendimethalin @ $0.75 \mathrm{~kg} / \mathrm{ha}$, pendimethalin @ 1.0 $\mathrm{kg} / \mathrm{ha}$, pendimethalin@0.75 kg/ha with hand weeding at 30 days after sowing, oxyfluorfen @ 0.15 $\mathrm{kg} / \mathrm{ha}$, oxyfluorfen $0.20 \mathrm{~kg} / \mathrm{ha}$, oxyfluorfen @ $0.15 \mathrm{~kg} / \mathrm{ha}$ with hand weeding at 30 days after sowing. Application of fluchloralin (pre-planting) @ $1.0 \mathrm{~kg}$ a.i./ha had maximum weed control efficiency (79.8\%), which was at par to pre-emergence application of pendimethalin1.0 kg/ha (78.7\%). The effect of these herbicides were also pronomced in terms of different growth and yield attributes of French bean crop and had maximum number of branches/plant (6.16 to 6.23), leaf area index (1.06 to 1.07), number of pods/plant (5.51 to 5.53) and 100-seed weight (316.2 to 316.7). The highest yield (1.11 to $1.10 \mathrm{t} / \mathrm{ha})$ and $N$ uptake $(52.52$ to $52.95 \mathrm{~kg} / \mathrm{ha})$ was noticed under fluchloralin or pendimethalin applied plot $1.0 \mathrm{~kg} / \mathrm{ha}$ also it had reduced $N$ losses through weeds. Economic evaluation in terms of returns Rs./Re invested was maximum under fluchloralin or pendimethalin applied plot reveals the significance of these herbicides in western Uttar Pradesh.

Key word- Weeds management, French bean, N-uptake and Economics

French bean (Phaseolus vulgaris L.) is one of the most important pulse crops cultivated in hilly tracts of Jammu and Kashmir, Himachal Pradesh, Uttar Pradesh and parts of Maharashtra as a kharif season crop due to its specific adaption to a cool and long growing season (Tripathi et al. 1986). In north eastern plains of India, this has been introduced as non-traditional winter season crop. In spite of its popularity, its productivity in India is very low $(300 \mathrm{~kg} / \mathrm{ha})$ as compared to the world average of $520 \mathrm{~kg} / \mathrm{ha}$ (Ali and Kushwaha, 1987).

Among the major constraints, initial heavy infestation weeds is one of the important factor, which hinders its overall growth and productivity (Malik and Malik, 1994) since initial growth rate of French bean is slow compared to weeds and the interspaces covered by weeds severely affected crop growth and yield. Although the yield losses due to weed depend on composition of weed flora, extent of infestation and the crop canopy decides yield loss but it has been estimated that weeds alone can reduce the yield to the tune of 20-60 per cent. Among the various weed management options herbicide use is not only efficient method but it is cost effective also. On the other had, physical weed control measure viz. hand weeding are safe but labour intensive. The present study deals with the optimizing herbicide treatments and its appropriate combination of hand weeding for obtaining maximum yield and profit and reducing weeds population upto thresh hold level.

\section{MATERIALS AND METHODS}

Field experiment was conducted at the research farm of Janta Vedic College Baraut, Baghpat Uttar Pradesh $\left(20.6^{0} \mathrm{~N}\right.$ and $77.15^{\circ} \mathrm{E}$ longitude at an elevation of $236.6 \mathrm{~m}$ above the sea level) during the rabi 2003-04 and 2004-05. Treatments were compared under randomized block design with three replications. The average annual rainfall of experimental site $651 \mathrm{~mm}$ extending over the period of mid July to October and few scattered showers during winter months from south-west monsoon. Whereas, the average minimum and maximum temperature vary from $5^{\circ} \mathrm{C}$ to $45^{\circ} \mathrm{C}$. The soil of the experimental field was sandy loam in texture, slightly alkaline in reaction, low in organic carbon $(0.35 \%)$ and available nitrogen $(235 \mathrm{~kg} / \mathrm{ha})$ and was medium in available phosphorus $(13.2 \mathrm{~kg} / \mathrm{ha})$ and potassium $(260.2 \mathrm{~kg} / \mathrm{ha})$. French bean variety "PDR-14" was sown in rows $30 \mathrm{x} 10 \mathrm{~cm}$ apart on 25 October during both the years using $120 \mathrm{~kg}$ seed/ha. Single super phosphate and muriate of potash were used to supply phosphorus and potassium at the rate of $60 \mathrm{~kg} \mathrm{P}_{2} \mathrm{O}_{5}$ per hectare as per treatment and $50 \mathrm{~kg} \mathrm{~K} \mathrm{~K}_{2} \mathrm{O}$ per hectare, respectively. A basal dose of half of the nitrogen $(60 \mathrm{~kg} / \mathrm{ha})$ was applied as per treatment and full dose of phosphorus and potassium was applied to the experimental plots by placement method just after demarcation of layout and the remaining half of Nitrogen $(60 \mathrm{~kg} / \mathrm{ha})$ was 
top dressed at maximum flowering stage. Fluchloralin was applied as pre-planting; pendimethalin and oxyfluorfen were applied pre-emergence with the help of knapsack sprayer fitted with flat fan T-jet nozzle at a spray volume of 500 litres. In weed free plots, weeds were removed manually as and when required with the help of khurpi. Other standard agronomical package and practices were followed uniformly in both the years. Weed and crop dry matter (DM) productions were measured at mid season and at final harvest. Different yield and yield attributing parameters were measured at the time of harvest and adjusted to 14\% moisture contents. For midseason sampling, weed and crop DM were measured from two using $0.25 \mathrm{~m}^{2}$ quadrats from each plot. At 90 days after sowing leaf area was measured by taking 10 leaves randomly from each plot and leaf area index (LAI) was computed. The weed control efficiency (WCE) of individual herbicide was calculated using following formula i.e.

WCE $=$ Weedy check treatment - Weed control treatment $\times 100$

Weedy check treatment

The $\mathrm{N}$ uptake through weeds as well as French bean crop was measuring Micro-Kjeldalal method (Black, 1965). The economic assessment of each treatment were made taking into the account of individual herbicide/labours use under weed control treatment and yield increase due to these treatment options. For this cost of herbicide was taken as Rs. 850/kg for fluchloralin, Rs. 1333/kg of pendimethalin and Rs 10500/kg of oxyfluorfen. The labour cost was Rs. 70.00/day and the economic cost of French bean was Rs. 45.00/kg grain. The treatment means were compared using ANOVA (Choran and coz, 1957).

\section{RESULTS AND DISCUSSION}

\section{Effect on weed growth}

Different herbicides as well as mechanical weed control measure had significant influence on weed population as their dry matter (Table 1). Among the herbicides used fluchloralin@1.0 kg/ha applied as pre-planting which was on par to pendimethalin @ $1.0 \mathrm{~kg} / \mathrm{ha}$ as pre-emergence had most effective weed control as compared to weedy check treatment in French bean. Of these the maximum reduction of weeds population was recorded in fluchloralin $1.0 \mathrm{~kg} / \mathrm{ha}(79.81 \%)$ followed by pendimethalin $1.0 \mathrm{~kg} / \mathrm{ha}$ treatments $(78.71 \%)$. Comparative performance of individual herbicides indicates that use of fluchloralin $1.00 \mathrm{~kg} / \mathrm{ha}$ or pendimethalin $1.00 \mathrm{~kg} / \mathrm{ha}$ had almost equal effect on weed control and these were $(50.53 \%)$ more effective than that of oxyfluorfen. Almost similar results were noticed for weed dry weight $\left(\mathrm{g} / \mathrm{m}^{2}\right)$ in French bean crop. Further, the gradient doses of herbicide use has also a significant effect on weed population and maximum efficacy was obtained at $1.0 \mathrm{~kg} / \mathrm{ha}$ of fluchloralin or pendimethalin dose, which had $79.52 \%$ and $78.38 \%$ respectively, more weed control efficiency over their $0.75 \mathrm{~kg} / \mathrm{ha}$ application rate and $60.81 \%$ and $70.28 \%$ respectively, over $0.75 \mathrm{~kg} / \mathrm{ha}$ along with hand weeding at 30 days after sowing.

The maximum efficacy of integrated HW and herbicide use may be ascribed in term of regrowth of weeds at grand growth stage i.e. 40-45 DAS. These results are in close conformity with the earlier report by Mishra et. al. (1999) and Prajapati et. al. (2003).

\section{Yield and yield attributes}

The weed control measures exhibited significant variation in respect of different growth parameters. Fluchloralin $1.00 \mathrm{~kg} / \mathrm{ha}$ produced taller plant closely followed by pendimethalin $1.0 \mathrm{~kg} / \mathrm{ha}$ as compared to weedy check treatment. The superiority of fluchloralin $1.0 \mathrm{~kg} / \mathrm{ha}$ and pendimethalin $1.0 \mathrm{~kg} / \mathrm{ha}$ at $90 \mathrm{DAS}$ stage in term of shoot height might have accrued due to better growth environment to the crop and non-smothering environment. This result confirms the findings of Mishra et al. (1998). The effect of fluchloralin@1.0 kg/ha or pendimethalin@1.0 kg/ha use was also seen in other growth parameters viz. number of branches (6.16 to 6.23) and leaf area index (1.06 to 1.07). The dry matter production which is the resultant of all these growth characters viz. plant height, 
number of branches/plant and leaf area index, was maximum under fluchloralin $1.00 \mathrm{~kg} / \mathrm{ha}$ and pendimethalin $1.0 \mathrm{~kg} / \mathrm{ha}$ treatments. The cumulative effect of all these growth parameters ultimately reflected on various yield attributes also and number of pods/plant, 1000-seed weight, Harvest Index was higher over other weed management options by 65.6 to $66.4 \%, 75.12$ to $75.23 \%$ and 75.47 to $75.93 \%$. Almost weed free situation under these treatments resulted in increased crop canopy development, which induced more nutrient and water uptake and better photosynthetic activities for French bean crop and ultimately resulted effective translocation of photosynthesis thousands grain development. (Dhanapal et al. 1989 and Rao et al. 1997).

\section{Nitrogen uptake}

Weed-management practices significantly affected the $\mathrm{N}$ uptake of French bean crop, the highest $\mathrm{N}$ uptake was recorded under the treatment of fluchloralin $1.00 \mathrm{~kg} / \mathrm{ha}$ and pendimethalin 1.00 $\mathrm{kg} / \mathrm{ha}(52.5 \mathrm{n}$ to $53 \mathrm{~kg} / \mathrm{ha}$ ) treated plot, which was significant at par to weed free situation. Such results may be visualized as lesser weed crop competition under these plots and thus more effective $\mathrm{N}$ uptake translocation towards the sink. The combined effect of more $\mathrm{N}$ content and yield was seen in terms of total uptake. The remaining weed management option did not prove significance in terms of $\mathrm{N}$ uptake value were significantly inferior to $1.0 \mathrm{~kg}$ fluchloralin or pendimethalin application (Table 3 ). The higher $\mathrm{N}$ uptake values may also be envisaged as decay of weeds after herbicidal treatment might have enriched the soil led more N supply to the French bean crop.

\section{Nitrogen depletion by weeds}

Use of various formulations of herbicides had significant influence on nitrogen removal by weeds. The maximum $\mathrm{N}$ depletion $(6.23 \mathrm{~kg} / \mathrm{ha})$ was noticed under weedy conditions followed by hand weeding $(5.28 \mathrm{~kg} / \mathrm{ha})$. The other herbicides or integrated weed-management practices significantly reduced the nitrogen depletion and maximum nitrogen drain was restricted with use of fluchloralin $1.00 \mathrm{~kg} / \mathrm{ha}$ or pendimethalin $1.00 \mathrm{~kg} / \mathrm{ha}(0.71 \mathrm{~kg} / \mathrm{ha})$, which was at par to the weedy check treatment. Hence it is pertinent mention that smaller and better crop smothering effect led to smaller $\mathrm{N}$ loss through weeds. Findings are its dose conformity with the reports of Mishra et. al. (1999).

\section{Economics}

The highest additional net returns were obtained due to higher sale price and higher seed yield respectively. The maximum additional net return due to weed management of Rs 21852 /ha was recorded under fluchloralin $1.00 \mathrm{~kg} / \mathrm{ha}$ treatment, which was at par of pendimethalin $1.00 \mathrm{~kg} / \mathrm{ha}$ treatment Rs 21189 /ha and the highest return/ rupees invests (Rs./Re investment) of (25.71 to 22.71) was recorded with fluchloralin $1.00 \mathrm{~kg} / \mathrm{ha}$ or pendimethalin $1.00 \mathrm{~kg} / \mathrm{ha}$. This showed that French bean is more responsive towards the inputs use and under good management and it can give even higher returns (Table 4).

Thus, the result of two year study clearly indicated that weed management practices in French bean crop by fluchloralin @ $1.00 \mathrm{~kg} / \mathrm{ha}$ and pendimethalin @ $1.00 \mathrm{~kg} / \mathrm{ha}$ treatments were recorded higher productivity and profitability of French bean

\section{REFERENCES}

Ali, M. and Kushwaha, B.L. 1987. Cultivation of rabi-rajmash in plain. Indian Farming 31 (5) 20-23.

Black, C.A 1965 Methods of soil analysis part II: American Society of Agronomy Madison Wisconsin, U.S.A, pp 1372-1376

Choran, W.G and Cox, G.M (1957). Experimental design, wiley, NY., USA

Dhanapal, GN, Reddy, BMV and Bomme, Gowda, A 1989. Screening of herbicide for dry land crops under Bangalore condition. Mysore Journal of Agricultural Sciences 23 (2) 159-163.

Malik, R. K. and Malik, Y.S. 1994. Development of herbicide resistance in India. In: Appropriate weed control in South East Asia-1994. 
Mishra, J.S., Singh, V.P. and Bhan, V.M. 1999. Studies on nitrogen economy in French bean (Phaseolus vulgaris) through weed control. Indian Journal of Weed Science 31 (3-4) 199-203.

Mishra, P.J., Sharma, S.N. and Satyanandan, K. 1998. Effect of herbicides on weed growth and yield of French bean (Phaseolus vulgaris L.) World Weeds 5 (1-2) 143146.

Prajapati, M. P. Patel, L. R. and Patel, B. M. 2003. Effects of integrated weed management and nitrogen level on weeds and productivity of French bean (Phaseolus vulgaris L.) under north Gujarat condition. Legume Research 26 (2) 79-84.

Rao, A.R., Sharma, S.N. and Mohammad, Shaik. 1997 Impact of varying plant population and herbicide use on weeds, crop yield and profitability of rajmash. Crop Research Hisar 13 (2) 293-300.

Tripathi, D.P., Chandra, S. and Asthana, A.N. 1986 Technology for growing rajmash in plains. Indian Farming 36 (9) 12-15. 


\section{(Tables \& Figures)}

Table 1. Weed population and dry weight in french bean at 60 DAS as influenced by herbicides management options

\begin{tabular}{|c|c|c|c|}
\hline Treatments & $\begin{array}{c}\text { Weed Population }\left(\text { no. } / \mathrm{m}^{2}\right) \text { in } \\
\text { French bean }\end{array}$ & $\begin{array}{c}\text { Dry weight of weeds }\left(\mathrm{g} / \mathrm{m}^{2}\right) \\
\text { in French bean }\end{array}$ & $\mathrm{WCE}(\%)$ \\
\hline Weedy Check & $20.01(4.53)$ & $17.53(4.25)$ & \\
\hline Hand weeding at $30 \mathrm{DAS}$ & $10.17(3.27)$ & $13.22(3.70)$ & 24.58 \\
\hline Weed free & $0.00(0.71)$ & $0.00(0.71)$ & 100.00 \\
\hline Fluchloralin (0.75 kg a.i./ha) & $7.69(2.86)$ & $6.45(2.64)$ & 63.20 \\
\hline Fluchloralin (1.00 kg a.i./ha) & $4.04(2.13)$ & $3.59(2.02)$ & 79.52 \\
\hline Fluchloralin (0.75 kg a.i./ha) + HW 30 DAS & $5.85(2.52)$ & $4.57(2.25)$ & 73.93 \\
\hline Pendimethalin (0.75 kg a.i./ha) & $7.48(2.82)$ & $6.87(2.71)$ & 60.81 \\
\hline Pendimethalin (1.00 kg a.i./ha) & $4.26(2.18)$ & $3.79(2.07)$ & 78.38 \\
\hline Pendimethalin (0.75 kg a.i./ha) + HW 30 DAS & $5.91(2.53)$ & $5.21(2.39)$ & 70.28 \\
\hline Oxyfluorfen (0.15 kg a.i./ha) & $8.01(2.92)$ & $7.96(2.91)$ & 54.59 \\
\hline Oxyfluorfen (0.20 kg a.i./ha) & $6.67(2.68)$ & $5.51(2.45)$ & 68.57 \\
\hline Oxyfluorfen (0.15 kg a.i./ha) + HW 30 DAS & $7.04(2.74)$ & $5.59(2.48)$ & 68.11 \\
\hline $\mathrm{SEm} \pm$ & 0.10 & 0.11 & 1.23 \\
\hline $\mathrm{CD}(\mathrm{P}=0.05)$ & 0.22 & 0.25 & 4.27 \\
\hline
\end{tabular}

Figures in parenthesis are transformed values subjected to $(\sqrt{ } x+0.5)$ transformation 
Table 2. Growth and yield attributes of french bean at 90 DAS as influenced by various herbicide treatment

\begin{tabular}{|c|c|c|c|c|c|c|c|}
\hline Treatments & $\begin{array}{l}\text { Plant height } \\
\qquad(\mathrm{cm})\end{array}$ & $\begin{array}{l}\text { No. of branches } \\
\text { / plant }\end{array}$ & $\begin{array}{l}\text { Dry matter } \\
\text { accumulation / } \\
\text { plant }(\mathrm{g})\end{array}$ & $\begin{array}{l}\text { Leaf area } \\
\text { index }\end{array}$ & $\begin{array}{c}\text { No. of } \\
\text { pods/plant }\end{array}$ & $\begin{array}{l}1000 \text {-seed } \\
\text { weight }(\mathrm{g})\end{array}$ & $\begin{array}{l}\text { Harvest } \\
\text { index }\end{array}$ \\
\hline Weedy Check & 20.09 & 4.09 & 7.01 & 0.73 & 2.76 & 237.9 & 28.99 \\
\hline Hand weeding at $30 \mathrm{DAS}$ & 22.69 & 4.79 & 7.19 & 0.85 & 3.08 & 252.5 & 31.87 \\
\hline Weed free & 27.35 & 6.48 & 9.99 & 1.08 & 5.70 & 323.7 & 39.85 \\
\hline Fluchloralin (1.00 kg a.i./ha) & 26.73 & 6.23 & 9.96 & 1.07 & 5.53 & 316.7 & 38.41 \\
\hline Fluchloralin (0.75 kg a.i./ha) + HW 30 DAS & 25.05 & 5.50 & 8.62 & 0.98 & 4.91 & 297.5 & 36.47 \\
\hline Pendimethalin (0.75 kg a.i./ha) & 24.66 & 5.40 & 8.10 & 0.87 & 4.29 & 271.5 & 33.59 \\
\hline Pendimethalin (1.00 kg a.i./ha) & 26.65 & 6.16 & 9.96 & 1.06 & 5.51 & 316.2 & 38.18 \\
\hline Oxyfluorfen (0.15 kg a.i./ha) + HW 30 DAS & 24.16 & 5.41 & 8.36 & 0.92 & 4.53 & 273.8 & 33.88 \\
\hline $\mathrm{SEm} \pm$ & 0.71 & 0.19 & 0.45 & 0.03 & 0.17 & 4.22 & 0.66 \\
\hline $\mathrm{CD}(\mathrm{P}=0.05)$ & 1.57 & 0.43 & 1.01 & 0.07 & 0.38 & 9.29 & 1.46 \\
\hline
\end{tabular}


Table 3. Effect of different weed management practices on $\mathrm{N}$-uptake $(\mathrm{kg} / \mathrm{ha}$ ) by weeds and french bean crop

\begin{tabular}{|c|c|c|}
\hline Treatments & $\mathrm{N}$ uptake $(\mathrm{kg} / \mathrm{ha})$ by weeds & $\mathrm{N}$ uptake $(\mathrm{kg} / \mathrm{ha})$ of French bean \\
\hline Weedy Check & $40.28(6.38)$ & 20.01 \\
\hline Hand weeding at $30 \mathrm{DAS}$ & $27.44(5.28)$ & 25.12 \\
\hline Weed free & $0.00(0.71)$ & 55.81 \\
\hline Fluchloralin (0.75 kg a.i./ha) & $10.46(3.31)$ & 35.14 \\
\hline Fluchloralin (1.00 kg a.i./ha) & $0.00(0.71)$ & 52.95 \\
\hline Fluchloralin (0.75 kg a.i./ha) + HW 30 DAS & $7.06(2.57)$ & 43.07 \\
\hline Pendimethalin (0.75 kg a.i./ha) & $10.48(3.31)$ & 34.76 \\
\hline Pendimethalin (1.00 kg a.i./ha) & $0.00(0.71)$ & 52.52 \\
\hline Pendimethalin (0.75 kg a.i./ha) + HW 30 DAS & $7.68(2.86)$ & 42.58 \\
\hline Oxyfluorfen (0.15 kg a.i./ha) & $13.22(3.70)$ & 29.63 \\
\hline Oxyfluorfen (0.20 kg a.i./ha) & $8.23(2.95)$ & 40.16 \\
\hline Oxyfluorfen (0.15 kg a.i./ha) + HW 30 DAS & $9.52(3.16)$ & 36.24 \\
\hline $\mathrm{S}$ Em \pm & 0.79 & 1.61 \\
\hline $\mathrm{CD}(\mathrm{P}=0.05)$ & 1.74 & 3.54 \\
\hline
\end{tabular}


Table 4. Yield and economics of french bean as influenced by different weed management practices

\begin{tabular}{|c|c|c|c|c|c|}
\hline Treatments & $\begin{array}{l}\text { Seed yield } \\
\text { (t/ha) }\end{array}$ & $\begin{array}{l}\text { Stover yield } \\
\text { (t/ha) }\end{array}$ & $\begin{array}{l}\text { Cost involve weed } \\
\text { management (Rs.) }\end{array}$ & $\begin{array}{c}\text { Additional net return } \\
\text { due to weed } \\
\text { management (Rs.) }\end{array}$ & $\begin{array}{l}\text { Return/ rupees } \\
\text { invests (Rs./Re } \\
\text { invests) }\end{array}$ \\
\hline Weedy Check & 0.53 & 1.06 & & & \\
\hline Hand weeding at $30 \mathrm{DAS}$ & 0.58 & 1.13 & 1050 & 885 & 0.84 \\
\hline Weed free & 1.06 & 1.59 & 4200 & 19402 & 4.62 \\
\hline Fluchloralin (0.75 kg a.i./ha) & 0.75 & 1.24 & 600 & 9277 & 15.46 \\
\hline Fluchloralin (1.00 kg a.i./ha) & 1.04 & 1.57 & 850 & 21852 & 25.71 \\
\hline Fluchloralin (0.75 kg a.i./ha) + HW 30 DAS & 0.86 & 1.47 & 1650 & 13110 & 7.95 \\
\hline Pendimethalin (0.75 kg a.i./ha) & 0.75 & 1.24 & 990 & 8752 & 8.84 \\
\hline Pendimethalin (1.00 kg a.i./ha) & 1.03 & 1.57 & 933 & 21189 & 22.71 \\
\hline Pendimethalin (0.75 kg a.i./ha) + HW 30 DAS & 0.86 & 1.47 & 2040 & 12427 & 6.09 \\
\hline Oxyfluorfen (0.15 kg a.i./ha) & 0.60 & 1.15 & 1045 & 1857 & 1.78 \\
\hline Oxyfluorfen (0.20 kg a.i./ha) & 0.82 & 1.47 & 1100 & 11157 & 10.14 \\
\hline Oxyfluorfen (0.15 kg a.i./ha) + HW 30 DAS & 0.76 & 1.28 & 2095 & 8052 & 3.84 \\
\hline $\mathrm{S} \mathrm{Em} \pm$ & 0.03 & 0.04 & - & - & - \\
\hline $\mathrm{CD}(\mathrm{P}=0.05)$ & 0.09 & 0.09 & - & - & - \\
\hline
\end{tabular}

